$10-2020$

\title{
A Tribute By Nicole Fernandez Ferrer: Kate Millett Memorial Service
}

Nicole Fernandez Ferrer

Follow this and additional works at: https://digitalcommons.uri.edu/dignity

\section{Recommended Citation}

Ferrer, Nicole Fernandez (2020) "A Tribute By Nicole Fernandez Ferrer: Kate Millett Memorial Service," Dignity: A Journal of Analysis of Exploitation and Violence: Vol. 5: Iss. 2, Article 18. https://doi.org/ 10.23860/dignity.2020.05.02.18

This Kate Millett Memorial Issue is brought to you for free and open access by DigitalCommons@URI. It has been accepted for inclusion in Dignity: A Journal of Analysis of Exploitation and Violence by an authorized editor of DigitalCommons@URI. For more information, please contact digitalcommons-group@uri.edu. 
A Tribute By Nicole Fernandez Ferrer: Kate Millett Memorial Service

Creative Commons License

(c) 1 (1) (9)

This work is licensed under a Creative Commons Attribution-Noncommercial-No Derivative Works 4.0 License. 


\section{DIGNITY}

Volume 5, Issue 2, Article 18, 2020
A JOURNAL ON

SEXUAL EXPLOITATION

AND VIOLENCE

\section{A TRIBUTE BY NICOLE FERNANDEZ FERRER: KATE MILLETT MEMORIAL SERVICE}

Nicole Fernandez Ferrer

Simone de Beauvoir Audio-Visual Centre, France

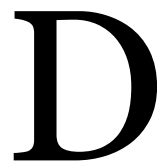

EAR KATE, DEAR EVERYONE,

It is with deep emotion I have the honor to pay tribute to Kate Millett, who passed away in Paris, the city I live in.

It was in Paris that I had the great privilege of meeting Kate, and it was there that we had planned to meet in September to pursue a common project, I will explain later.

Very early on, your books, which arrived in France with a year's delay, were my thoughtful companions, of struggles and passions. Sexual Politics, translated into La Politique du Mâle, gave a double meaning to the caustic irony: Mâle=Male and Mal=Evil.

This book's very refined analysis of the patriarchy as a political and cultural institution signaled the possibility for women's assertiveness, control over their bodies, and sexual liberation: "Sex is social class with political implications"

In 1975, two years after the publication of your book The Prostitution Papers, as a strike of prostitutes exploded in France, you debated prostitution and questioned the role of the patriarchy in the exploitation and persecution of minorities with French feminists among others: Monique Witting and Christine Delphy. Delphine Seyrig, who was filming the state of prostitution, was the translator. A film, included in the collection of the audiovisual Simone de Beauvoir Center, which I direct, is entitled Kate Millett and discusses prostitution with feminists. This film is still very much viewed and discussed. You say:

It is by opposing one another (mothers and prostitutes) that men control us, and even if true that prostitution is in one way is a kind of slavery, at no cost must one despise prostitutes...the prostitutes feel condemnation when one condemns prostitution; it is about attaining a comprehension, a solidarity with the prostitutes.

Between 1975 and 1978, in your book Flying and Sita, you share intimate thoughts with great strength, which moved deeply the lesbian militant feminist that I am.

In Upstate New York, always a pioneer in your actions, you created the Farm, a woman's art colony, which you define as follows: "We created a paradise, a selfsustained colony including women who have worked hard at what we love to do: art and community." 
In 1979, after the Shah's fall, you were in Iran with Sophie and other feminists during the large Iranian women's demonstrations. Everything you recorded, photographed, and filmed you got out of the country, in spite of your expulsion and the repression. Upon your return during a press conference at the Mutuality in Paris, end of March 1979, you clearly declare: "If women don't get equal rights to men, it wasn't worth bringing down tyranny."

You visited Paris regularly to see Simone de Beauvoir every year during a 16 years period until 1986. Those visits were important for me. They nourished me...A very important person for me left my life. She was a mentor for me. I learned to live thanks to Simone de Beauvoir's books.

Four years ago, you and Sophie wished to donate all your work on the Iranian women to the Simone de Beauvoir audiovisual center, in Paris, for its conservation, documentation, and appraisal. It was at the same time a great joy and enormous responsibility to welcome all this unique material in our collection with our partners, the French National Library and the National Film Center. We have started working with this collection.

Since this meeting concerning the material "Iran 1979," I shared with you, dear Kate, and with Sophie, working sessions, animated discussions, lots of generous big laughs, and great meals. You liked the French language, and when a word escaped in English, you translated.

You climbed the four flights of stairs to our location to meet my staff: An unforgettable sharing moment.

In the film: Tribute from Kate Millett to Simone de Beauvoir, filmed by Anne Fraisander in 1986, you said: with The Second Sex Simone de Beauvoir opened a door and told us why we must live, why we needed to fight to be free human beings, why we need to transcend our condition in a patriarchal society.

By these words, you have pointed out, "we have taken the reins and must hold on tight. Simone de Beauvoir has proved that feminism is a great humanism. We are a great historical force; nothing can stop us."

In response, I would say, Kate, with all your writing, your artworks, your life, your passions, and your militancy with the women of the whole world, you amplified the vision and life of Simone de Beauvoir.

Rest In Peace, Kate.

\section{AUTHOR BIOGRAPHY}

Nicole Fernandez Ferrer is the director of the Simone de Beauvoir Audio-Visual Center in Paris, France. http://2020.cityofwomen.org/en/content/nicole-fernandez-ferrer

\section{RECOMMENDED CITATION}

Ferrer, Nicole Fernandez. (2020). A tribute by Nicole Fernandez Ferrer: Kate Millet memorial service, Dignity: A Journal of Sexual Exploitation and Violence. Vol. 5, Issue 2, Article 18. https://doi.org/10.23860/dignity.2020.05.02.18 Available at http://digitalcommons.uri.edu/dignity/vol5/iss2/18. 